\title{
KINETICS MODELS OF LIGNIN ISOLATION FROM RICE HUSK USING ALKALINE HYDROGEN PEROXIDE
}

\author{
Anwar Ma'ruf 1, 2, * , Bambang Pramudono², Nita Aryanti ${ }^{2}$
}

https://doi.org/10.23939/chcht13.02.224

\begin{abstract}
This study explained the kinetics and mechanisms for the delignification and extraction of lignin from rice husk with alkaline hydrogen peroxide in water. The results showed that both the delignification and extraction models can be used to describe the kinetics of lignin isolation. Based on the SSE (sum squared error) values from the non-linear regressions, the delignification model fitted the experimental data better than the extraction model. The values of the activation energy were determined for the mass transfer control model, the reaction control model, and the extraction model.
\end{abstract}

Keywords: lignin isolation, kinetics model, delignification, rice husk.

\section{Introduction}

The lignin content in biomass ranges from 20 to $30 \%$ depending on the type of lignocellulose [1]. There are two types of studies performed on the lignin isolation process, namely a delignification study on the pulping process [2-4], and lignin isolation or lignin extraction in the effort of lignin utilization [5-10]. However, in one investigation, both processes can be combined. The kinetic and mechanistic investigations are important for both the delignification and extraction processes of lignin. Kinetic and mechanistic studies are necessary to understand how to control the lignin removal process effectively and how to select the appropriate conditions conducive to remove lignin selectively.

In previous investigations, the kinetics of lignin isolation from biomass was approximated by the kinetics of the delignification process. Da Silva Perez and Curvelo [2] studied the delignification kinetics of Eucalyptus urograndis using an acetone-water pulping medium. Shatalov and Pereira [11] studied the alkaline organosolv

\footnotetext{
${ }^{1}$ Universitas Muhammadiyah Purwokerto, Jawa Tengah 53182, Indonesia

${ }^{2}$ Diponegoro University, Jawa Tengah 50239, Indonesia

*anwarump@yahoo.com

(C) Ma'ruf A., Pramudono B., Aryanti N., 2019
}

delignification kinetics of Arundo donax L. using ethanol as the medium. Guolin et al. [12] studied the pulping kinetics of wheat straw using an aqueous caustic potashammonia process. Ho et al. [13] studied the delignification kinetics of rice straw using tetrahydrofurfuryl alcohol with $\mathrm{HCl}$. Kim and Holtzapple [14] studied the delignification kinetics of corn stover using lime pretreatment. Macfarlane et al. [15] studied process intensification kinetics of delignification using a batch reactor. Huang et al. [16] studied the pulping kinetics of rice straw pulping and the mechanism of delignification of a process that utilized ammonium hydroxide $\left(\mathrm{NH}_{4} \mathrm{OH}-\right.$ $\mathrm{KOH}$ ). Cui et al. [17] studied the sulfate (kraft) pulping kinetics of wheat straw, which used aqueous $\mathrm{NaOH}$ and $\mathrm{Na}_{2} \mathrm{~S}$. Song et al. [18] studied the delignification reaction kinetics of wheat straw in 1-methyl-3-ethyl bromide imidazole, a neutral ionic liquid solvent.

In the previous works the kinetics models of isothermal delignification were described as pseudo-firstorder and pseudo-second-order ones. While the kinetics model of lignin extraction has not been studied yet. The purpose of this study was to examine the kinetics and mechanisms of lignin isolation from rice husk by alkaline hydrogen peroxide based on delignification model and extraction model. Based on the delignification model, the effect of mass transfer and chemical reaction is discussed. While based on the extraction model, only the mass transfer is discussed.

\section{Experimental}

\subsection{M aterials}

Rice husks were obtained from Banyumas in Central Java, Indonesia. Hydrogen peroxide $(30 \%$ solution) and sodium hydroxide were obtained from Merck (Darmstadt, Germany). Demineralized water was obtained from the laboratory at the Department of Chemical Engineering at Universitas Muhammadiyah Purwokerto (Jawa Tengah, Indonesia). 


\subsection{Investigation Procedure}

The lignin isolation process was conducted using an alkaline hydrogen peroxide solution. $40 \mathrm{~g}$ of rice husk (pulverized rice husk that passes through a 40-mesh screen but is retained on a 60 -mesh screen) was added to $500 \mathrm{ml}$ flask that contained $430 \mathrm{ml}$ of $1.5 \%$ aqueous solution of $\mathrm{H}_{2} \mathrm{O}_{2}$. Sodium hydroxide $(2 \mathrm{~N})$ was added to the flask until the mixture had $\mathrm{pH}$ of 11 . The mixture was then heated to $313 \mathrm{~K}$ using a hot water bath. Once the mixture reached $313 \mathrm{~K}$, a sample $(1 \mathrm{ml})$ was taken from the flask every $10 \mathrm{~min}$. The samples were analyzed for the amount of lignin and silica extracted.

\subsection{Analytical Methods}

The amount of lignin dissolved in the aqueous sample was analyzed using a Shimadzu UV-Vis Spectrophotometer (UV-1800; Shimadzu Corporation, Tokyo, Japan) with a wavelength resolution of $1 \mathrm{~nm}$. Lignin concentration was determined at the wavelength of $280 \mathrm{~nm}$. The silica concentration in the sample liquor was determined by using a Shimadzu AAS (AA-6300; Shimadzu Corporation, Tokyo, Japan). The bulk lignin concentration in the solid rice husk was calculated using Eq. (1):

$$
[L]_{s}=\frac{x \cdot m-[L]_{1} \cdot V}{m}
$$

where $[L]_{s}-$ the lignin concentration in the solid rice husk, $\mathrm{g}$ lignin/g rice husk; $x$ - the lignin content in the rice husk, $\% ; m-$ the mass of rice husk, g; $[L]_{1}-$ the lignin concentration in the aqueous liquor phase, $\% ; V-$ the volume of the aqueous solvent, $\mathrm{ml}$.

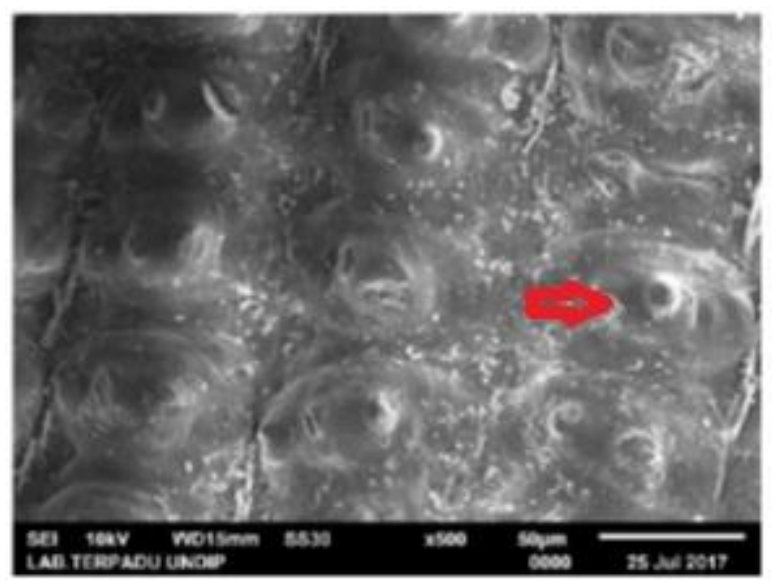

a)

\section{Results and Discussion}

The authors' previous study reported that rice husks had a lignin content of $18.81 \%$ [19]. Fig. 1 describes the surface of rice husk before and after the isolation process. Small circles show cellulose while the surrounding is lignin (arrows). During the lignin isolation process the surface becomes convex. Lignin isolation from rice husk has a side product. Silica in rice husk reacts with alkali $(\mathrm{NaOH})$ to form $\mathrm{NaSiO}_{3}$ (sodium silicate), which is precipitated.

Fig. 2 shows the amount of lignin and silica dissolved in the liquid phase during the aqueous alkaline peroxide treatment of the rice husks. Delignification was conducted within the temperature range of 313-343 K. Higher delignification temperatures resulted in higher lignin and silica concentrations in the aqueous phase.

The optimum time for the process was $80 \mathrm{~min}$. After this time the aqueous concentrations of lignin and silica were relatively constant. Cui et al. [17] reported that optimum time for the delignification of wheat straw using soda-anthraquinone (SAQ) pulping was $90 \mathrm{~min}$. Dong et al. [20] reported that the optimum time for delignifying wheat straw was 60 min using a formic acid. In most cases, delignification proceeds through three phases, namely initial, bulk, and residual [21].

By using Eq. (1), the concentration of residual lignin in the rice husk solids can be determined. The concentration of residual lignin in the solids is shown in Fig. 3. Based on observations from the lignocellulosic pulping kinetics of lignin removal, it was concluded that the alkaline peroxide process could be divided into three delignification phases: an initial phase from 0 to $20 \mathrm{~min}$, a bulk phase from 20 to $80 \mathrm{~min}$, and a residual phase from 90 to $120 \mathrm{~min}$.

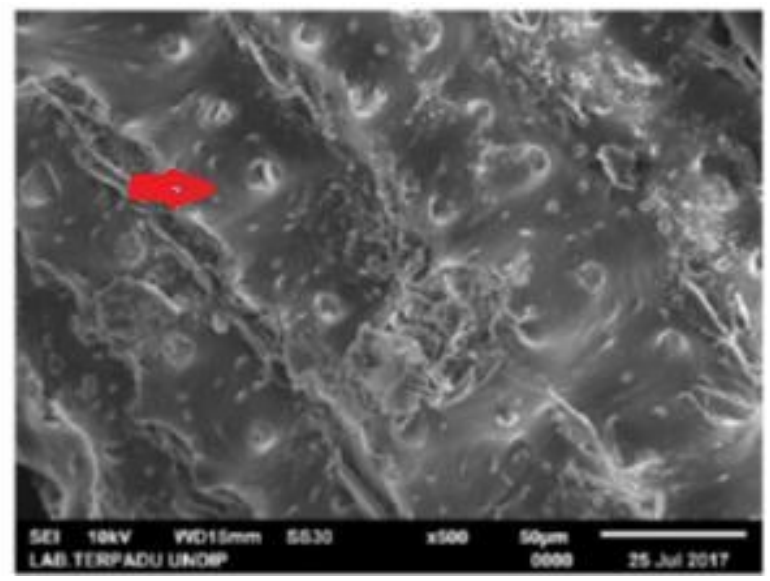

b)

Fig. 1. Morphology of rice husk before (a) and after (b) isolation 


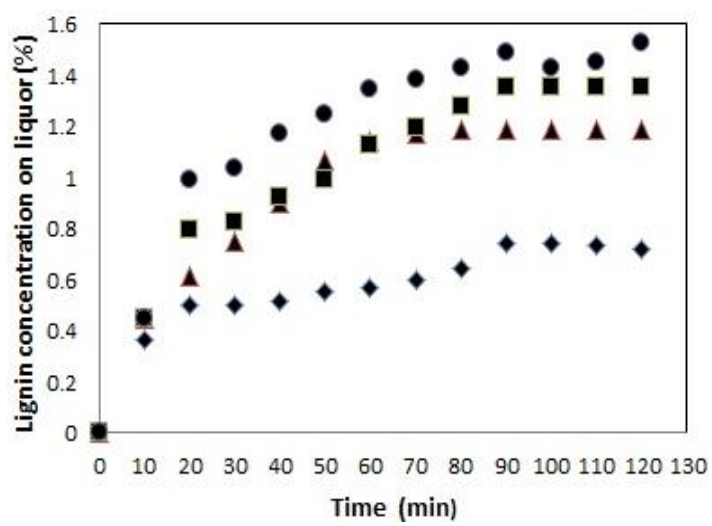

a)

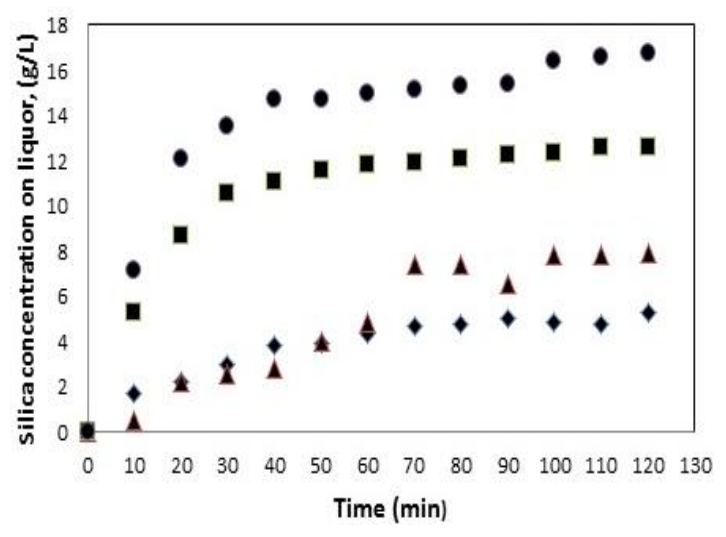

b)

Fig. 2. Concentration profiles of lignin (a) and silica (b) in the aqueous phase during alkaline peroxide treatment of rice husks at $313 \mathrm{~K}(\bullet)$; $323 \mathrm{~K}(\boldsymbol{\Delta})$; $333 \mathrm{~K}(\boldsymbol{\bullet})$ and $343 \mathrm{~K}(\bullet)$

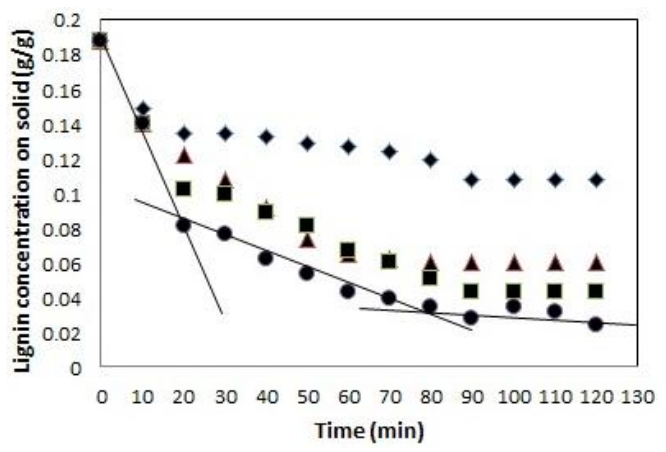

Fig. 3. Concentration profile of lignin in the solid rice husk during alkaline peroxide treatment at $313 \mathrm{~K}(\bullet)$; $323 \mathrm{~K}(\boldsymbol{\Delta}) ; 333 \mathrm{~K}(\boldsymbol{\bullet})$ and $343 \mathrm{~K}(\bullet)$

\subsection{Kinetics of Delignification Models}

The delignification model for the alkaline peroxide treatment was developed based on the residual lignin concentration in the biomass, i.e. rice husk. Abdul-Karim et al. [22] reported that the delignification process was controlled by chemical reaction kinetics; the authors noted that the mass transfer resistances of delignification were negligible. Commonly, the delignification process was assumed to follow pseudo-first-order kinetics [11, 14, 15, $18,20]$. However, there are several investigators that assume that delignification follows second-order-reaction kinetics [12, 17, 21].

The delignification model assumed that delignification occurred through four mechanistic steps: (1) formation of hydroxyl radicals; (2) hydroxyl radical transport from the bulk liquid through the film layer surrounding the solid to the reaction site within the bulk solid; (3) reaction of hydroxyl radicals with lignin in the solid; and (4) dissolution of lignin fragments into the bulk liquid phase. The four steps are described in details as follows:
(1) The formation of hydroxyl radicals $\left(\mathrm{HO}^{\circ}\right)$.

$$
\begin{aligned}
2 \mathrm{H}_{2} \mathrm{O}_{2} & \rightarrow \mathrm{HO}^{\bullet}+\mathrm{O}^{2 \cdot \bullet}+\mathrm{H}^{+}+\mathrm{H}_{2} \mathrm{O} \\
r_{1} & =\frac{d\left[H O^{\bullet}\right]_{1}}{d t}=k^{\bullet} \cdot\left[\mathrm{H}_{2} \mathrm{O}_{2}\right]
\end{aligned}
$$

It is difficult to determine the concentration of hydroxyl radicals $\left[\mathrm{HO}^{\circ}\right]_{1}$ in the reaction system. Therefore, it is assumed that their concentration is equal to the concentration of hydroxyl ions:

$$
r_{1}=\left[H O^{\bullet}\right]_{1}=\left[H O^{-}\right]_{1}
$$

where $\left[\mathrm{HO}_{1}\right]_{1}$ is the hydroxyl ions concentration in the bulk liquid, mol/l.

(2) Hydroxyl radical transport (Fig. 4).

$$
\begin{aligned}
& r_{2}=D \cdot\left[\mathrm{HO}^{-}\right]_{1}-\left[\mathrm{HO}^{-}\right]_{s} \\
& r_{2}=D \cdot\left[\mathrm{HO}^{-}\right]_{1}-H \cdot\left[\mathrm{HO}^{-}\right]_{1}
\end{aligned}
$$

where $D-$ the diffusivity coefficient, $\min ^{-1} ;[H O]_{s}-$ hydroxyl ions concentration in the bulk solid, mol/g solid), and $H$ - Henry's law constant, 1/g solid.

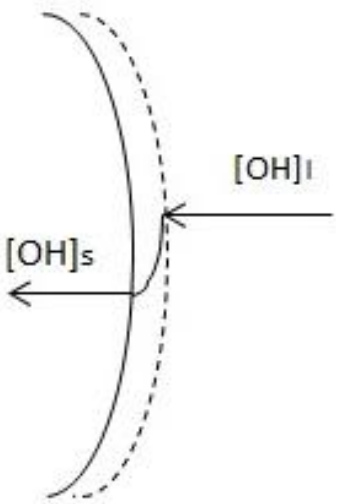

Fig. 4. Film mass transfer of hydroxide ions from bulk liquid to bulk solid phases 
(3) The reaction of hydroxyl radicals with lignin in the bulk solid.

$$
r_{3}=k \cdot[L]_{s} \cdot\left[H O^{-}\right]_{s}^{n}=k \cdot[L]_{s} \cdot H \cdot\left[H O^{-}\right]_{1}^{n}
$$

where $k$ - the chemical reaction rate constant, $1^{n} \cdot \mathrm{mol}^{-n} \cdot \mathrm{min}^{-1}$; $[L]_{s}-$ the lignin concentration in the bulk solid, g lignin/g solid; $n-$ the reaction order of $\left[\mathrm{HO}^{-}\right]$, and $[L]_{1}-$ lignin concentration in the bulk liquid, $\mathrm{g}$ lignin $/ \mathrm{ml}$. liquid.

(4) The dissolution of lignin fragment into the bulk

$$
r_{4}=D^{\prime} \cdot\left([L]_{s}-[L]_{1}\right)
$$

\subsection{M ass Transfer and Chemical Reaction Control}

The first delignification model is one that is controlled by mass transfer phenomena. With this model, it is assumed that mechanistic steps (1) and (4) are very fast, and therefore can be ignored. Mass balance equations around the bulk solid and bulk liquid phases can be written based on mechanistic steps (2) and (3):

$$
\begin{gathered}
\frac{d[L]_{s}}{d t}=-k \cdot[L]_{s} \cdot H \cdot\left[H O^{-}\right]_{1}^{n} \\
\frac{d\left[H O^{-}\right]_{1}}{d t}=\frac{m}{V} \cdot k \cdot[L]_{s} \cdot H \cdot\left[H O^{-}\right]_{1}^{n}-D \cdot\left\{\left[H O^{-}\right]_{1}-H \cdot\left[H O^{-}\right]_{1}\right\}
\end{gathered}
$$

The calculation of model parameters was carried out for the reaction times between 0 and $80 \mathrm{~min}$, i.e., initial and bulk phases. Fig. 5 illustrates the fitted models for mass transfer controlled delignification. Table 1 shows the parameter values obtained based on this model. The value of SSE (sum square of errors) ranged from 0.0003 to 0.0013 ; these values indicated that the mass transfer model was sufficient to describe the mechanism of the delignification process.

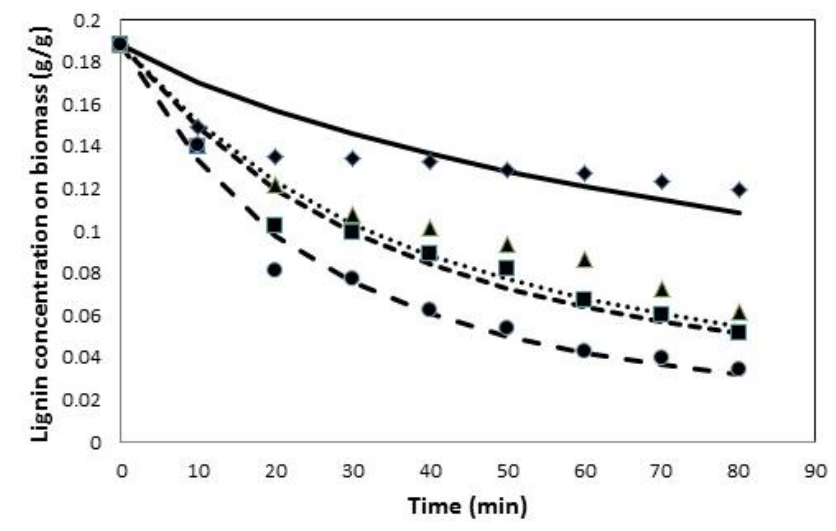

Fig. 5. Fitting of delignification data at $313 \mathrm{~K}(\diamond)$; $323 \mathrm{~K}(\boldsymbol{\Delta})$; $333 \mathrm{~K}(\boldsymbol{\bullet})$ and $343 \mathrm{~K}(\bullet)$ to the mass transfer model at $313 \mathrm{~K}(-) ; 323 \mathrm{~K} \mathrm{(…);} 333 \mathrm{~K}(--)$ and $343 \mathrm{~K}(---)$
The reaction order for lignin in this study was fixed at the value of 1 , while the reaction order for $\left[\mathrm{HO}^{-}\right]$was calculated. The calculations indicated that the reaction order for $\left[\mathrm{HO}^{-}\right]$averaged to 0.44 value. Huang et al. [16] reported a reaction order of 1 with respect to lignin and a reaction order of 0.30 with respect to $\left[\mathrm{HO}^{-}\right]$when delignifying rice straw with $\mathrm{NH}_{4} \mathrm{OH}-\mathrm{KOH}$. Cui et al. [17] reported a reaction order of 0.7 for the delignification of wheat straw using soda-anthraquinone pulping process.

The values of chemical reaction rate constant $(k)$ varied; they ranged from 0.99136 to $1.005763 \mathrm{l}^{0.44} \cdot \mathrm{mol}^{-0.44} \cdot \mathrm{min}^{-1}$. Huang et al. [16] reported values of the chemical reaction rate constant that ranged from 0.0053 to $0.0711^{0.30} \cdot \mathrm{mol}^{-0.30} \cdot \mathrm{min}^{-1}$ for their pulping study.

The values for diffusivity varied from 0.59478 to $0.6050 \mathrm{~min}^{-1}$. Diffusivity generally increases with increasing temperature; in such cases, diffusivity can be correlated to temperature by the Arrhenius expression, i.e., $D=D_{0} \exp \left(\frac{-Q d}{R T}\right)$. However, the diffusivities in this study (Table 1), which were calculated from the nonlinear data regressions, did not appear to increase as the reaction temperature increased.

The values for Henry's law coefficient $(H)$ ranged from 0.37644 to $0.42129 \mathrm{l} / \mathrm{g}$ solid. The relationship between Henry's law coefficient and the temperature can be related to the following expression:

$$
\ln H=A+B T^{1}
$$

A plot of $\ln H$ versus $1 / T$ data will yield the values of $A$ (y-intercept) and $B$ (slope); such a plot for the data in this study is shown in Fig. 6. The value of $A$ was determined as 0.2232 , while the value of $B$ was determined as -372.08 .

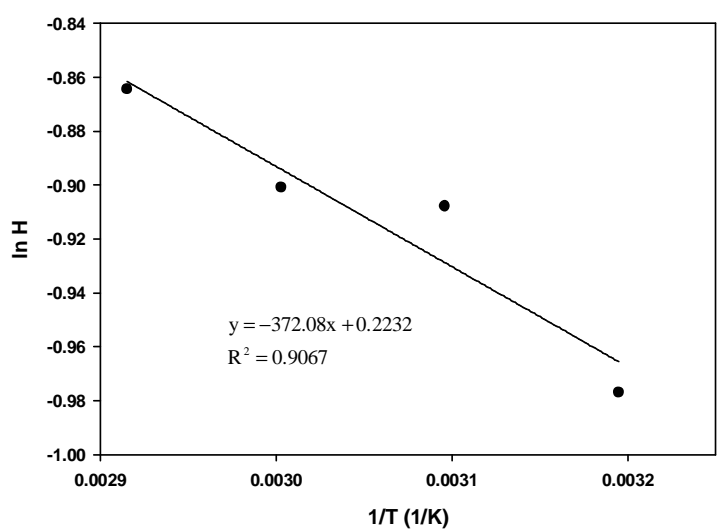

Fig. 6. Determination of Henry's law coefficient 
Parameters of the mass transfer model for alkaline peroxide delignification of rice husk solids

\begin{tabular}{|c|c|c|c|c|c|}
\hline Temperature, $\mathrm{K}$ & $k$ & $D$ & $n$ & $H$ & SSE \\
\hline 313 & 0.99136 & 0.605041 & 0.497184 & 0.37644 & 0.001334 \\
\hline 323 & 1.00109 & 0.599418 & 0.432544 & 0.40336 & 0.001101 \\
\hline 333 & 1.00216 & 0.599348 & 0.427328 & 0.40621 & 0.000501 \\
\hline 343 & 1.005763 & 0.594785 & 0.396490 & 0.42129 & 0.000354 \\
\hline
\end{tabular}

\subsection{Chemical Reaction Control}

Another mathematical model was tested to represent the alkaline peroxide delignification process. This model assumes that the delignification process is limited by a chemical reaction control and that mass transfer resistances are negligible. The delignification reaction was assumed to follow a pseudo-first-order rate:

$$
\begin{aligned}
& \frac{d[L]_{s}}{d t}=k^{\prime}[L]_{s} \\
& \ln \left(\frac{L}{L_{0}}\right)=-k^{\prime} t
\end{aligned}
$$

where $k^{\prime}$ is the chemical reaction rate constant, $\min ^{-1}$.

Fig. 7 shows the non-linear regression of the data to the models of mass transfer and reaction control. Table 2 shows the parameter values obtained based on the curvefitting of the second model to the experimental data. The statistical SSE values ranged from 0.001295 to 0.002188 , which indicated that the second model was sufficient to describe the mechanism of the delignification process.

Calculations of the chemical reaction rate constants were performed for the entire reaction time. The value of the chemical reaction rate constant varied from 0.0069 to $0.0238 \mathrm{~min}^{-1}$ (Table 2). These values are similar to the value of organosolv delignification of Arundo donax L. in the initial delignification phase [11].

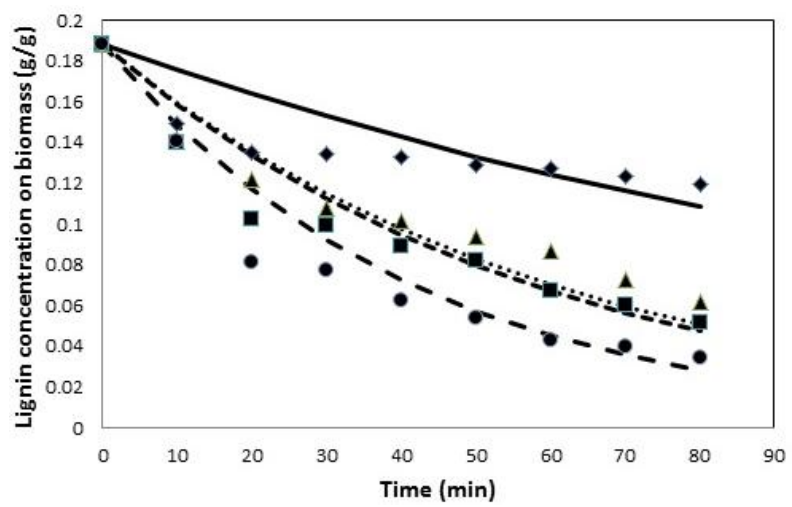

Fig. 7. Fitting of experimental delignification data at $313 \mathrm{~K}(\bullet)$; $323 \mathrm{~K}(\boldsymbol{\Delta})$; $333 \mathrm{~K}(\boldsymbol{\bullet})$ and $343 \mathrm{~K}(\bullet)$ to chemical reaction control models at $313 \mathrm{~K}($ (-); $323 \mathrm{~K}(\cdots \cdots)$; $333 \mathrm{~K}(---)$ and $343 \mathrm{~K}$ $(---)$

Table 2

Chemical reaction rate constants of the second model for the alkaline peroxide delignification of rice husk solids

\begin{tabular}{|c|c|c|}
\hline Temperature, $\mathrm{K}$ & $k^{\prime}$ & SSE \\
\hline 313 & 0.0069 & 0.002188 \\
\hline 323 & 0.0164 & 0.001295 \\
\hline 333 & 0.0172 & 0.00152 \\
\hline 343 & 0.0238 & 0.001728 \\
\hline
\end{tabular}

The relationship between chemical reaction rate constant and temperature can be expressed by the Arrhenius equation:

$$
\begin{gathered}
k=A \exp \left(\frac{-E_{a}}{R T}\right) \\
\ln k=\ln A-\frac{E_{a}}{R T}
\end{gathered}
$$

where $A$ - the Arrhenius constant (or frequency factor); $E_{\mathrm{a}}$ - the activation energy, $\mathrm{kJ} \cdot \mathrm{mol}^{-1} ; R$ - the universal gas constant $\left(R=8.314 \mathrm{~J} \cdot \mathrm{mol}^{-1} \cdot \mathrm{K}^{-1}\right) ; T$ - the absolute temperature, $\mathrm{K}$.

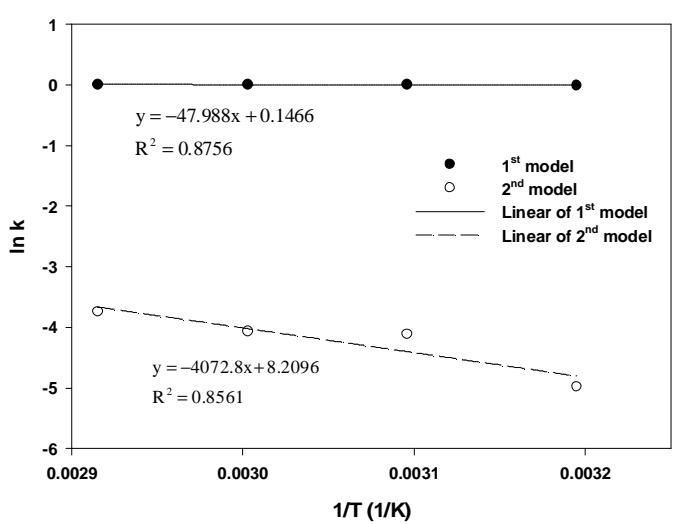

Fig. 8. Arrhenius plot of $\ln k$ versus $1 / T$ for two alkaline peroxide delignification models

Fig. 8 shows the plot of $\ln k$ versus 1/T. Table 3 shows the values of the parameters of Arrhenius equation from the linear regression. The mass transfer control model of delignification had the $E_{\mathrm{a}}$ value of $0.389 \mathrm{~kJ} \cdot \mathrm{mol}^{-1}$, while for the chemical reaction control model $E_{\mathrm{a}}=33.681 \mathrm{~kJ} \cdot \mathrm{mol}^{-1}$. The value of $E_{\mathrm{a}}$ for the second 
model was similar to other reported values for delignification processes. For initial delignification, the value of $E_{a}$ given in the literature is $40-60 \mathrm{~kJ} \cdot \mathrm{mol}^{-1}$ [11].

Table 3

Kinetics parameters of two delignification models

\begin{tabular}{|l|c|c|}
\hline \multicolumn{1}{|c|}{ Parameters } & $A$ & $E_{a}, \mathrm{~kJ} \cdot \mathrm{mol}^{-1}$ \\
\hline $\begin{array}{l}\text { Mass transfer control } \\
\text { model (first) }\end{array}$ & $1.1578 \cdot 10^{3}$ & 0.398 \\
\hline $\begin{array}{l}\text { Chemical reaction control } \\
\text { model (second) }\end{array}$ & $3.676 \cdot 10^{3}$ & 33.861 \\
\hline
\end{tabular}

\subsection{Extraction Kinetics M odel}

\subsubsection{Extraction model of lignin extraction}

An developed extraction model is based on the active compound being extracted into the solvent. Based on the extraction model, the kinetics model of lignin extraction is described as the mass transfer occurring at solid-liquid interface [23, 24]:

$$
\frac{d[L]_{l}}{d t}=k_{e, L}\left\{[L]_{l, e}-[L]_{l}\right\}
$$

where $k_{e, L}$ - the mass transfer coefficient for lignin, $\min ^{-1}$; $[L]_{l, e}$ - the lignin concentration in the solvent at equilibrium, g lignin $/ \mathrm{ml}$.

A non-linear regression of Eq. (13) to the experimental delignification data was performed to obtain the value of the mass transfer coefficient for the lignin extraction model. Fig. 9 shows the curve-fitting of the model to the laboratory data. Table 4 shows the value of the mass transfer coefficient and the lignin concentration at equilibrium. The values of mass transfer coefficients of lignin extraction were slightly higher than those for the pseudo-first-order reaction rate constant, i.e., second delignification model.

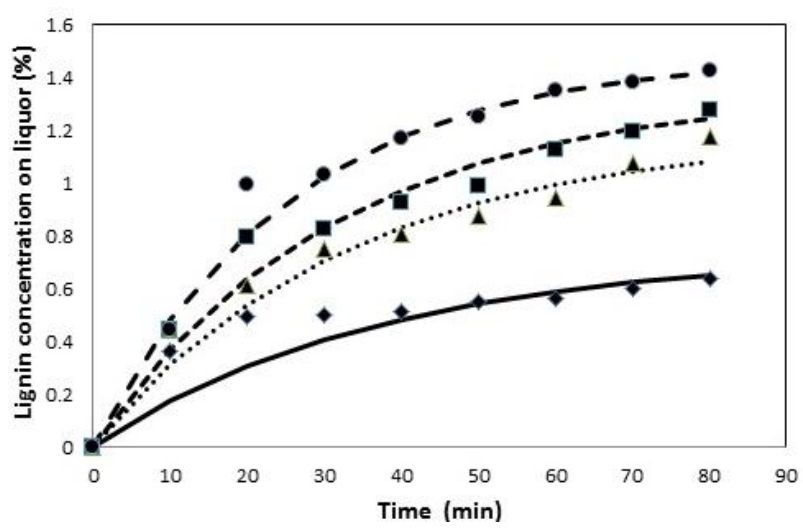

Fig. 9. Non-linear regression of delignification data at $313 \mathrm{~K}(\bullet)$; $323 \mathrm{~K}(\boldsymbol{\Delta})$; $333 \mathrm{~K}(\boldsymbol{\bullet})$ and $343 \mathrm{~K}(\bullet)$ to the extraction model (Eq. (13)) at $313 \mathrm{~K}(-)$; $323 \mathrm{~K}(\cdots \cdot \cdots)$; $333 \mathrm{~K}(--)$ and $343 \mathrm{~K}(---)$
Table 4

Mass transfer coefficients for the lignin extraction model (Eq. 13)

\begin{tabular}{|c|c|c|c|}
\hline Temperature, $\mathrm{K}$ & $k_{e, L}$ & {$[L]_{l, e}$} & SSE \\
\hline 313 & 0.0264 & 0.740909 & 0.0839 \\
\hline 323 & 0.0303 & 1.184242 & 0.0403 \\
\hline 333 & 0.0318 & 1.350379 & 0.0436 \\
\hline 343 & 0.0392 & 1.486037 & 0.0366 \\
\hline
\end{tabular}

\subsubsection{Extraction model of silica extraction}

Similar to the extraction model for lignin, an extraction model for silica extraction can be expressed by the equation:

$$
\frac{d[S i]_{l}}{d t}=k_{e, S i}\left\{[S i]_{l, e}-[S i]_{l}\right\}
$$

where $k_{e, S i}$ - the mass transfer coefficient for silica, $\min ^{-1}$; $[S i]_{l, e}$ - the silica concentration in the extraction solvent at equilibrium, g silica/l.

Non-linear regression of Eq. (14) to the laboratory data was performed to obtain the value of the mass transfer coefficient for the silica extraction model. Fig. 10 shows the curve-fitting of the extraction model to the silica removal data. Table 5 shows the value of the mass transfer coefficient and the silica concentration at equilibrium.

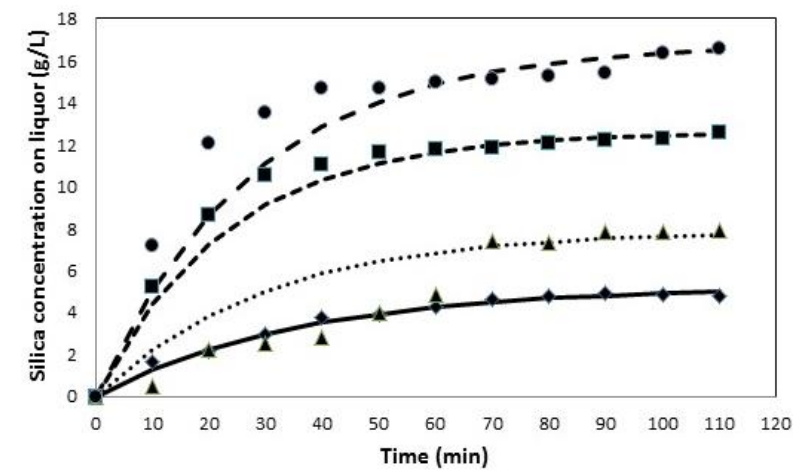

Fig. 10. Non-linear regression of silica removal data at $313 \mathrm{~K}$ $(\bullet) ; 323 \mathrm{~K}(\boldsymbol{\Delta})$; $333 \mathrm{~K}(\boldsymbol{\bullet})$ and $343 \mathrm{~K}(\bullet)$ to the extraction model (Eq. (14)) at $313 \mathrm{~K}(-)$; $323 \mathrm{~K}(\cdots \cdots)$; $333 \mathrm{~K}(---)$ and $343 \mathrm{~K}(---)$

Table 5

Mass transfer coefficients for the silica extraction model (Eq. 14)

\begin{tabular}{|c|c|c|c|}
\hline Temperature, $\mathrm{K}$ & $k_{e, S i}$ & {$[S i]_{l, e}$} & SSE \\
\hline 313 & 0.0278 & 5.24463 & 0.3452 \\
\hline 323 & 0.0336 & 7.90706 & 31.0625 \\
\hline 333 & 0.0428 & 12.6215 & 5.3985 \\
\hline 343 & 0.0362 & 16.78912 & 26.7828 \\
\hline
\end{tabular}

The Arrhenius expression can be applied to the mass transfer coefficient for lignin and silica extraction models. 
According to Table 5, an uncommon condition on the silica extraction model was observed, i.e., the mass transfer coefficient at $343 \mathrm{~K}$ was lower than that at $333 \mathrm{~K}$. This resulted in a statistical $R^{2}$ of 0.58 for the linear regression to the Arrhenius expression (Fig. 11). The activation energy for the lignin extraction model was $10.966 \mathrm{~kJ} \cdot \mathrm{mol}^{-1}$. Dos Santos et al. [24] reported that the average activation energies for the extraction process of Jatropha curcas seeds using anhydrous ethanol is $18.61 \mathrm{~kJ} \cdot \mathrm{mol}^{-1}$.

Table 6

Kinetics parameters of delignification model

\begin{tabular}{|c|c|c|}
\hline Parameters & $A$ & $E_{a}, \mathrm{~kJ} \cdot \mathrm{mol}^{-1}$ \\
\hline Lignin extraction & 1.775177 & 10.966 \\
\hline Silica extraction & 1.100429 & 9.416 \\
\hline
\end{tabular}

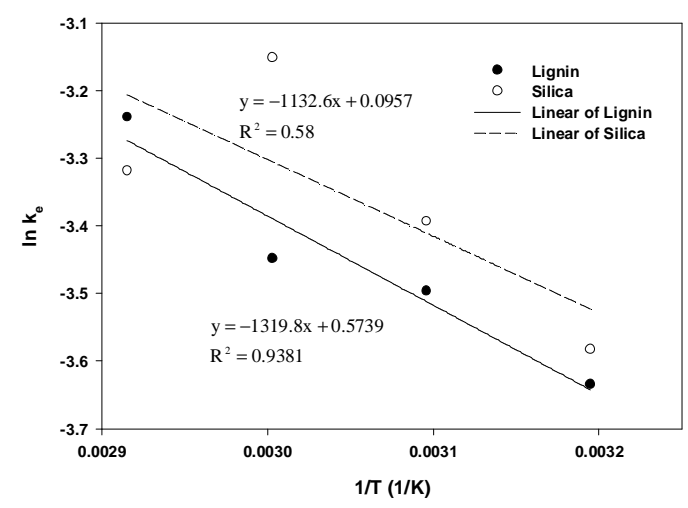

Fig. 11. Arrhenius plot of $\ln k_{e}$ versus $1 / T$ for the mass transfer models for lignin and silica extraction

\section{Conclusions}

The results of analysis show that both the delignification and extraction models can be used to describe the mechanistic and kinetics of isolation of lignin from rice husk. The delignification model with the pseudo-first-order (chemical reaction control model) is recommended because of more simple than chemical and reaction control model. The values of the activation energy were $0.398,33.861$ and $10.972 \mathrm{~kJ} \cdot \mathrm{mol}^{-1}$ for the mass transfer control model, the reaction control model, and the extraction model, respectively. The value for the activation energy of silica extraction was $9.416 \mathrm{~kJ} \cdot \mathrm{mol}^{-1}$.

\section{Acknowledgements}

This study was supported by Postgraduate Research Team of Ministry of Research, Technology and Higher Education.

\section{References}

[1] Tolbert A., Akinosho H., Khunsupat R. et al.: Biofuel. Bioprod. Bioref., 2014, 8, 836. https://doi.org/10.1002/bbb.1500
[2] Perez D., Curvelo A.: Open Agric. J., 2010, 4, 145.

[3] Fuertez J., Ruiz A., Alvarez H., Molina A.: Dyna, 2011, 78, 175.

[4] Wen J., Sun S., Yuan T. et al.: Bioresour. Technol., 2013, 150,

278. https://doi.org/10.1016/j.biortech.2013.10.015

[5] Tan S. et al.: Green Chem., 2009, 11,437.

https://doi.org/10.1039/b905678p

[6] Li Z., Ge Y.: J. Braz. Chem. Soc., 2011, 10, 1866.

https://doi.org/10.1590/S0103-50532011001000006

[7] Xin Q., Pfeiffer K., Prausnitz J. et al.: Biotechnol. Bioeng., 2012, 109, 346. https://doi.org/10.1002/bit.24337

[8] Cui J., Sun H., Wang X. et al.: Ind. Crops Prod., 2015, 74, 689.

https://doi.org/10.1016/j.indcrop.2015.05.061

[9] Mohtar S. et al.: Bioresour. Technol., 2015, 192, 212.

https://doi.org/10.1016/j.biortech.2015.05.029

[10] Watkins D., Nuruddin M., Hosur M. et al.: J. Mater. Res.

Technol., 2015, 4, 26. https://doi.org/10.1016/j.jmrt.2014.10.009

[11] Shatalov A., Pereira H.: Ind. Crops Prod., 2005, 21, 203.

https://doi.org/10.1016/j.indcrop.2004.04.010

[12] Guolin H., Chengfang Z., Zhongsheng C.: Chinese J. Chem.

Eng., 2006, 14, 729. https://doi.org/10.1016/S1004-9541(07)60003-2

[13] Ho C., Wu K., Wang E., Su Y.: Ind. Eng. Chem. Res., 2011, 50,

3849. https://doi.org/10.1021/ie102184c

[14] Kim S., Holtzapple M.: Bioresour. Technol., 2006, 97, 778. https://doi.org/10.1016/j.biortech.2005.04.002

[15] Macfarlane A., Farid M., Chen J.: Chem. Eng. Process., 2009, 48, 864. https://doi.org/10.1016/j.cep.2008.11.005

[16] Huang G., Shi J., Langrish T.: Bioresour. Technol., 2007, 98,

1218. https://doi.org/10.1016/j.biortech.2006.05.002

[17] Cui M., Song W., Liu Z.: Adv. Mater. Res., 2014, 860/863, 1012.

[18] Song W., Deng Y., Xu Y.: J. Chem. Pharm. Res., 2015, 7, 527.

[19] Ma'ruf A., Pramudono B., Aryanti N.: AIP Conf. Proceed., 2017, 1823. https://doi.org/10.1063/1.4978086

[20] Dong L., Zhao X., Liu D.: RSC Adv., 2015, 5, 20992.

https://doi.org/10.1039/C4RA14634D

[21] Epelde I., Lindgren C., Lindström M.: J. Wood Chem. Technol., 1998, 18, 69. https://doi.org/10.1080/02773819809350126

[22] Abdul-Karim L., Rab A., Polyanszky E., Rusznak I.: Tappi J., 1995, 78, 161.

[23] Amarante R., Oliveira P., Schwantes F., Morón-Villarreyes J.: Ind. Eng. Chem. Res., 2014, 16, 6824. https://doi.org/10.1021/ie500508n

[24] Dos Santos S., Martins M., Caneschi A. et al.: Int. J. Chem. Eng., 2015, 2015. https://doi.org/10.1155/2015/871236

Received: January 16, 2018 / Revised: February 02, 2018 / Accepted: June 03, 2018

\section{КІНЕТИЧНІ МОДЕЛІ ВИДІЛЕННЯ ЛІГНІНУ 3 РИСОВОГО ЛУШПИННЯ 3 ВИКОРИСТАННЯМ ЛУЖНОГО ПЕРОКСИДУ ВОДНЮ}

Анотація. Досліджено кінетику і механізми делігніфікаиії та екстракції лігніну з рисового лушпиння лужним пероксидом водню у воді. Показано, щьо для опису кінетики виділення лігніну можуть використовуватися як делігніфікачійна, так і екстракційна моделі. На основі значень методу СКП (сума квадратів помилок) з нелінійних регресій, модель делігніфікаиії краше узгоджується з експериментальними даними, ніж екстракційна модель. Визначено значення енергї активації для моделі керування масопереносом, моделі керування реакиією та моделі екстракиії.

Ключові слова: виділення лігніну, модель кінетики, делігніфікація, рисове лушпиння. 